\title{
Stocking density during the initial grow-out phase of tambatinga in net pens
}

\author{
Densidade de estocagem durante a recria da tambatinga em tanque-rede
}

\author{
Ana Paula Oeda Rodrigues ${ }^{{ }^{*}}$ Adriana Ferreira Lima ${ }^{\mathrm{I}}$ \\ Patricia Oliveira Maciel ${ }^{\mathrm{I}}$ Patrícia Resplandes Rocha dos Santos ${ }^{\mathrm{I}}$ \\ Roberto Manolio Valladão Flores ${ }^{\mathrm{I}}$ Adriano Prysthon da Silva ${ }^{\mathrm{I}}$
}

ABSTRACT

The aim of this study was to determine the most adequate stocking density for tambatinga during the initial grow-out phase in net pens, considering fish growth, health, and financial aspects. Three stocking densities (400, 500, and 600 fish $\left.\mathrm{m}^{-3}\right)$ were evaluated for 60 days in a completely randomized design $(n=4)$. There were no significant differences among the stocking densities for growth performance parameters, but yield was higher in the density of 600 fish $\mathrm{m}^{-3}\left(3,909.43 \pm 397.79 \mathrm{~kg} \mathrm{~m}^{-3}\right)$ compared to 400 fish $\mathrm{m}^{-3}\left(2,656.43 \pm 665.45 \mathrm{~kg} \mathrm{~m}^{-3}\right)$. Glucose, hematocrit, and total plasma proteins levels did not differ among treatments. The production was economically feasible for the three stocking densities. However, the density of 600 fish $\mathrm{m}^{-3}$ showed the highest profit. According to the results, 600 fish $\mathrm{m}^{-3}$ is the most adequate density for the initial grow-out phase of tambatinga in net pens.

\section{Key words: + Colossoma macropomum $x \quad \precsim$ Piaractus brachypomus, small-scale fish farming, growth performance, economic analysis.}

\section{RESUMO}

$O$ objetivo deste trabalho foi determinar a melhor densidade de estocagem para a tambatinga durante a fase de recria em tanques-rede, considerando o desempenho zootécnico, sanitário e econômico. Foram avaliadas três densidades de estocagem (400, 500 e 600 peixes $\mathrm{m}^{-3}$ ) durante 60 dias, em delineamento inteiramente ao acaso $(n=4)$. Não houve diferença para os indices de desempenho analisados entre as densidades de estocagem avaliadas, com exceção da produtividade, que foi maior para a densidade de 600 peixes $m^{-3}\left(3909,43 \pm 397,79 \mathrm{~kg} \mathrm{~m}^{-3}\right)$ em comparação à densidade de 400 peixes $m^{-3}(2656,43 \pm 665,45 \mathrm{~kg}$ $\left.m^{-3}\right)$. Glicose plasmática, hematócrito e proteinas plasmáticas não diferiram entre os tratamentos. A produção foi economicamente viável nas três densidades de estocagem avaliadas. No entanto, a densidade de 600 peixes $\mathrm{m}^{-3}$ apresentou maior lucro em comparação às demais. A melhor densidade de estocagem para a recria da tambatinga em tanque-rede é de 600 peixes $\mathrm{m}^{-3}$.

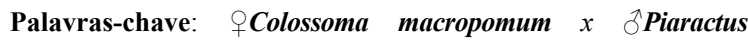 \\ brachypomus, piscicultura familiar \\ desempenho, análise econômica.
}

\section{INTRODUCTION}

Small-scale fish farming plays an important role in improving food security, by increasing fish consumption (a highly nutritional food item) and supplementing family income, contributing to the alleviation of poverty and promoting social and economic development (KAWARAZUKA \& BÉNÉ, 2010; FAO, 2011). Furthermore, fish farming may provide a better use of the natural resources available in the property and also become a means of entertainment to the families (KUBITZA \& ONO, 2010). In the state of Tocantins, small-scale fish farming has been initiated by a joint action between the Brazilian Ministry of Fisheries and Aquaculture and the Tocantins state agency for rural extension and it has been growing ever since as an alternate source of food production and income for local farmers (SILVA et al., 2013; LIMA et al., 2014). The fish most produced in Tocantins in such system is tambatinga, a hybrid between the female tambaqui (Colossoma macropomum) and the male pirapitinga (Piaractus brachypomus). Although studies with this hybrid are scarce, it is widely produced in the North and Midwest of Brazil because it combines the desirable traits of both species, such as the tambaqui rapid growth and the pirapitinga high deposition of dorsal meat (HASHIMOTO et al., 2012).

\footnotetext{
'Empresa Brasileira de Pesquisa Agropecuária, Embrapa Pesca e Aquicultura, Quadra 104 Sul, Avenida LO 1, Conjunto 4, 77020-020, Palmas, TO, Brasil. E-mail: anapaula.rodrigues@embrapa.br. "Corresponding author.
} 
Nevertheless, most of the small-scale fish farms in the state of Tocantins are not conducted in technically adequate earthen ponds, e.g., lack of water inlet and outlet for complete pond emptying to eliminate potential predators. Accordingly, many farmers stock tambatinga juveniles in handmade net pens instead of releasing them directly in the ponds or reservoirs (SILVA et al., 2013). Initial grow-out phase before the actual grow-out phase has not been practiced by most round-fish farmers in Brazil, but it is a means to optimize the production structure and reduce the initial losses in grow-out due to predation in ponds and reservoirs (LIMA et al., 2013). Additionally, to produce large juvenile fish in the initial grow-out phase and sell to fish farmers whose production cycle is limited to six months a year due to the dry season is also a potential market in the region. This would optimize production cycle and final fish weight. Stocking density has been reported to affect fish survival, growth, health and yield in tambaqui (BRANDÃO et al., 2004), matrinxã Brycon amazonicus (BRANDÃO et al., 2005), and pirarucu Arapaima gigas (OLIVEIRA et al., 2012). However, the optimum stocking density for tambatinga in the initial grow-out phase has not been determined. This study evaluated the optimum stocking density for tambatinga during the initial grow-out phase in net pens according to fish growth, health, and profit.

\section{MATERIAL AND METHODS}

The experiment was conducted in a reservoir of approximately $0.25 \mathrm{ha}$ for 60 days between November 2013 and January 2014. Juvenile tambatinga $(0.34 \pm 0.11 \mathrm{~g})$ were purchased from a commercial fish farm and distributed into 12 net pens $\left(1.0 \mathrm{~m}^{3} ; 1.0 \times 1.0 \times 1.0 \mathrm{~m}, 3-\mathrm{mm}\right.$ mesh) in a completely randomized design. The cages were arranged in line, with 2-m spacing between them.

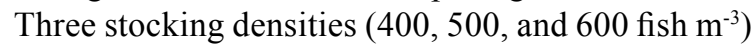
were evaluated in quadruplicate.

Fish were fed a commercial extruded feed (40\% crude protein; $2-4 \mathrm{~mm}$ pellet size) three times a day, six times a week, at a feeding rate of $10 \%$ biomass. In the first 15 days of the experiment, fish were fed crushed feed (1-mm pellet size). Uneaten feed was deducted to calculate feed intake and feed conversion ratio. Fish weight was determined every 15 days to monitor fish growth and adjust feed amount.

Water quality parameters were measured at 40-cm depth in the water-flow direction, after the net pens and 10-m away from the net pens. Water dissolved oxygen, temperature, and $\mathrm{pH}$ were measured in the morning, six times a week with a multiparameter probe $\left(4.0 \pm 0.7 \mathrm{mg} \mathrm{L}^{-1}, 27.4 \pm 0.8^{\circ} \mathrm{C}\right.$, and $6.4 \pm 0.2$, respectively). Total ammonia $\left(1.60 \pm 0.76 \mathrm{mg} \mathrm{L}^{-1}\right)$ and conductivity $\left(19.40 \pm 5.71 \mu \mathrm{S} \mathrm{cm} \mathrm{cm}^{-3}\right)$ were measured weekly with the same probe, while colorimetric kits were used to measure alkalinity $(11.14 \pm 2.27 \mathrm{mg}$ $\left.\mathrm{CaCO}_{3} \mathrm{~L}^{-1}\right)$ and hardness $\left(8.14 \pm 2.27 \mathrm{mg} \mathrm{CaCO}_{3} \mathrm{~L}^{-1}\right)$.

\section{Growth parameters}

Ten percent of fish in each net pen was weighed every 15 days. At the end of the experiment, all fish in the net pens was weighed in groups of 50 individuals and the standard length was measured in $10 \%$ of the fish per net pen. To assess fish growth during the 60 days period, the following variables were calculated: (1) weight gain $(\mathrm{g})=$ fish final weight - fish initial weight; (2) specific growth rate $(\% \mathrm{SGR} /$ day $)=[\ln ($ fish final weight $)-\ln ($ fish initial weight)]/days of experiment x 100; (3) coefficient of variation of the standard length $(\%)=$ (standard deviation of standard length/mean standard length) $\mathrm{x} 100$; (4) feed conversion ratio = total feed intake/ total weight gain; (5) mortality $=$ (initial number of fish - final number of fish)/initial number of fish $\mathrm{x}$ 100; (6) fish yield $\left(\mathrm{kg} \mathrm{m}^{-3}\right)=$ final biomass/net pen volume.

One-hundred fish were sampled at the beginning of the experiment to determine initial body crude protein and gross energy contents (AOAC, 1999). At the end of the experiment, fifteen fish per experimental unit were sampled to determine final body composition. Apparent protein and energy retention rates were calculated according to the following formula: protein/energy retention rate $(\%)=[($ final biomass $x$ final body protein/energy $)-$ (initial biomass $\mathrm{x}$ initial body protein/energy)]/total protein/energy intake.

\section{Blood parameters}

At the end of the experiment, five fish per replicate were anesthetized with eugenol (INOUE et al., 2011) for blood sampling by puncture of the caudal vein. Plasma glucose $\left(\mathrm{mg} \mathrm{dL}^{-1}\right)$ was determined with a clinical portable glucometer (Accu-Chek Performa, Roche $^{\circledR}$ ) (CHAGAS et al., 2007). Hematocrit (\%) was determined by the microhematocrit method, and total plasma proteins $\left(\mathrm{g} \mathrm{dL}^{-1}\right)$ were determined with a clinical analogical portable refractometer.

\section{Economic parameters}

The structure of the production operating cost proposed by the Institute of Agricultural Economics (IEA, Brazil) and widely addressed in the economics literature (FURLANETO et al., 2006; 
SABBAG et al., 2011) was adopted in this study considering the following components: (1) Actual Operating Cost $(\mathrm{AOC})=$ actual expenditure made during the productive process to acquire juvenile fish, fish feed, water quality analysis kit, operation of machinery/equipment and others; (2) Total Operating Cost $($ TOC $)=$ actual operating cost plus expenditure with depreciation of any improvement made; (3) Total Cost $(\mathrm{TC})=$ total operating cost plus capital remuneration of improvements and machinery.

Inputs considered in this financial model are those actually used in the experiment of fish production, and the prices are those practiced in the region. Labor cost is an important production factor but it was not considered because local farmers usually use their own or family member's work force and do not hire people in their fish farms.

To calculate income, it was considered that the entire production was sold at market price ( $\mathrm{R} \$$ 0.50 per $5-10 \mathrm{~cm}$ juvenile tambatinga). Thus, the gross income (GI) was calculated by multiplying the total number of juvenile fish by the individual market price.

To compare the economics of the three stocking densities tested, financial analysis considered production in four net pens, in a 60-day cycle and the following feasibility indicators: (1) Gross margin: GI-AOC; (2) Net margin: GI-TOC; (3) Profit: GI-TC.

Statistical analysis

Fish growth and blood parameters values were subjected to analysis of variance (ANOVA), followed by Tukey test at $\mathrm{P}<0.05$ to detect statistical differences between means. The assumptions of the mathematical model for homoscedasticity and normality of the residues were checked. Values are expressed as mean \pm standard deviation.

\section{RESULTS AND DISCUSSION}

Water quality parameters were within the desired range for tambaqui (ARAÚJO LIMA \& GOULDING, 1998) and other tropical freshwater fishes (MORO et al., 2013). Water alkalinity and hardness values were below the minimum recommended for freshwater fish farming (MORO et al., 2013). Optimum levels of those parameters have not been reported for tambatinga but tambaqui naturally inhabits waters with low alkalinity and hardness without affecting growth (BRAND ̃̃O et al., 2004; SILVA et al., 2007a).

No significant difference was detected in the growth parameters between the stocking densities tested, but yield was higher in the density of 600 fish $\mathrm{m}^{-3}$ probably due to the higher number of animals in the net pens as fish final weight did not differ among treatments (Table 1). Fish growth was low as final body weight ranged between 7.55 and $8.27 \mathrm{~g}$ and standard length between 5.84 and $6.17 \mathrm{~cm}$. Juvenile tambaqui stocked in net pens at four densities $(200,300,400$, and 500 fish $\mathrm{m}^{-3}$ ) for 60 days resulted in higher final weight $(16.47-23.80 \mathrm{~g})$ and total length $(9.80-10.74 \mathrm{~cm})$

Table 1 - Growth performance and blood variables of juvenile tambatinga stocked at three densities and cultured for 60 days in net-pens.

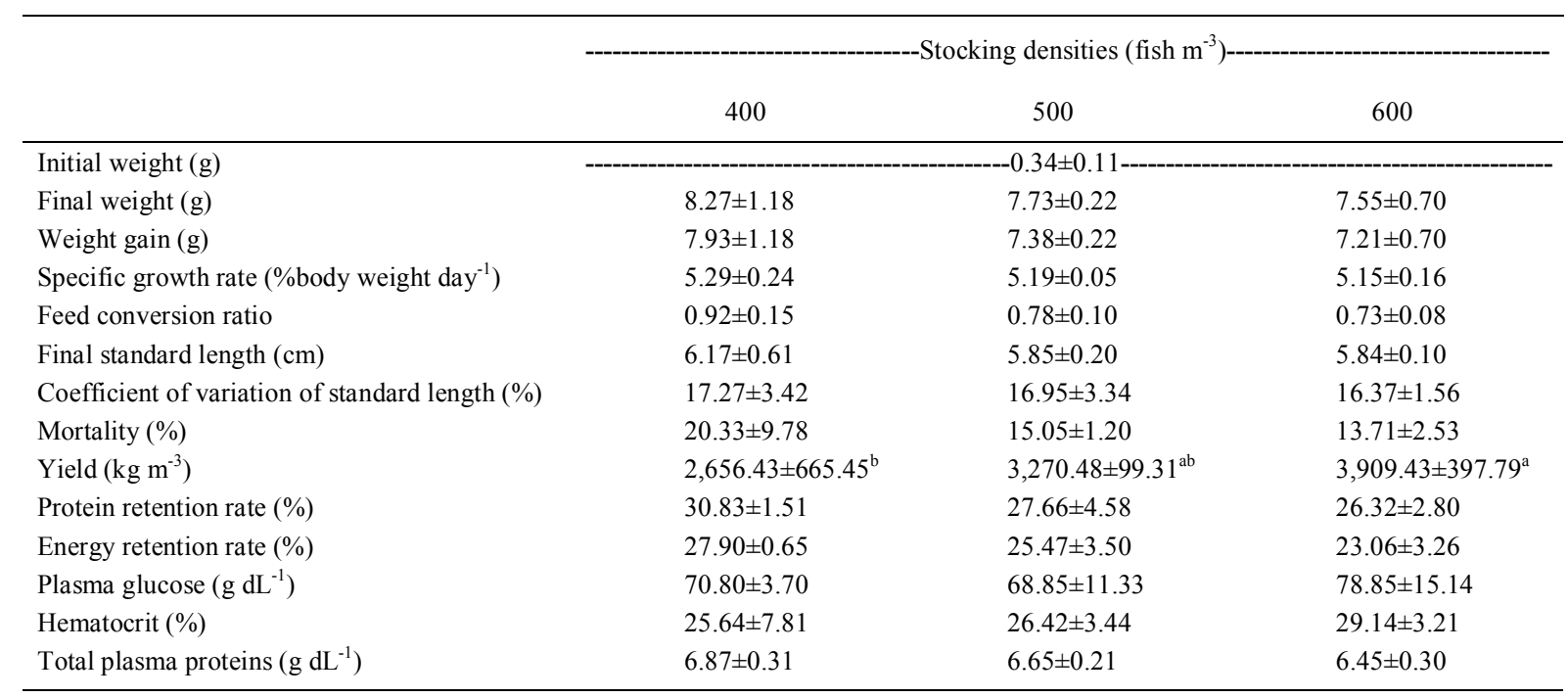

${ }^{a, b}$ Different letters in the same row indicate significant differences by the Tukey test $(\mathrm{P}<0.05)$.

Ciência Rural, v.46, n.1, jan, 2016. 
(BRANDÃO et al., 2004). However, factors such as high frequency of rainfall during the experiment (58.3\% of the days), which inhibited feed intake and often caused the suspension of feeding, may have impaired the growth of tambatinga juveniles. Such negative relationship between rain and food consumption in fish culture has also been observed by ANRAS (1995). Consequently, feed intake was as low as $5.6 \%$ and $4.7 \%$ biomass in the first and second months, respectively, although feeding rate was set at $10 \%$ biomass, as suggested by SILVA et al. (2007a). Thus, the low feed conversion ratio found in this study may be due to low feed intake during the experiment.

The coefficient of variation (CV) of the standard length, which indicates heterogeneity in growth (PETIT et al., 2001), did not differ as a function of stocking density, as reported for tambaqui (BRANDÃO et al., 2004) values ranging from 9.54 to $19.91 \%$ after 60 days in the initial grow-out phase. Mortality was not influenced by stocking density and it was below those found for tambaqui during the initial grow-out phase in net pens (16.0-31.2\%) (BRANDÃO et al., 2004) and in earthen ponds (50.94-52.42\%) (SILVA et al., $2007 b$ ). Stocking density did not affect protein and energy retention rates, reflecting the efficient use of food nutrients by tambatinga juveniles. Despite the low growth observed in tambatinga juveniles, food use was not compromised, and both growth and nutrient use were within the range found for tambaqui (KOHLA et al., 1992) and other species such as jundiá Rhamdia quelen (MORO et al., 2010) and piracanjuba Brycon orbignyanus (BORBA et al., 2003).

The values for blood variables analyzed in the present study did not differ between treatments (Table 1), indicating that no physiological damage caused by stress as a function of stocking density occurred. Assessment of physiological indicators of stress is an important tool to understand adaptation processes in fish (GOMES et al., 2006). Glucose is a primary source of energy in fish, and an increase in glucose levels in the blood occurs as a secondary response to stress (BRAUN et al., 2010). Similarly, increase in erythrocyte concentration is related to a greater oxygen demand in stress conditions (BRAUN et al., 2010), whereas variation in total plasma protein is an indicator of osmotic imbalance (WEDEMEYER, 1996). The values for glucose, hematocrit, and plasma proteins obtained for tambatinga were similar to those for tambaqui (BRANDÃO et al., 2004; CHAGAS et al., 2005; 2007).

Cost structure per production unit (fish) and per production cycle using four net pens is presented in table 2 for each stocking density

Table 2 - Costs and financial indicators for the production of tambatinga juveniles in four net pens at three stocking densities and 60-day cycle.

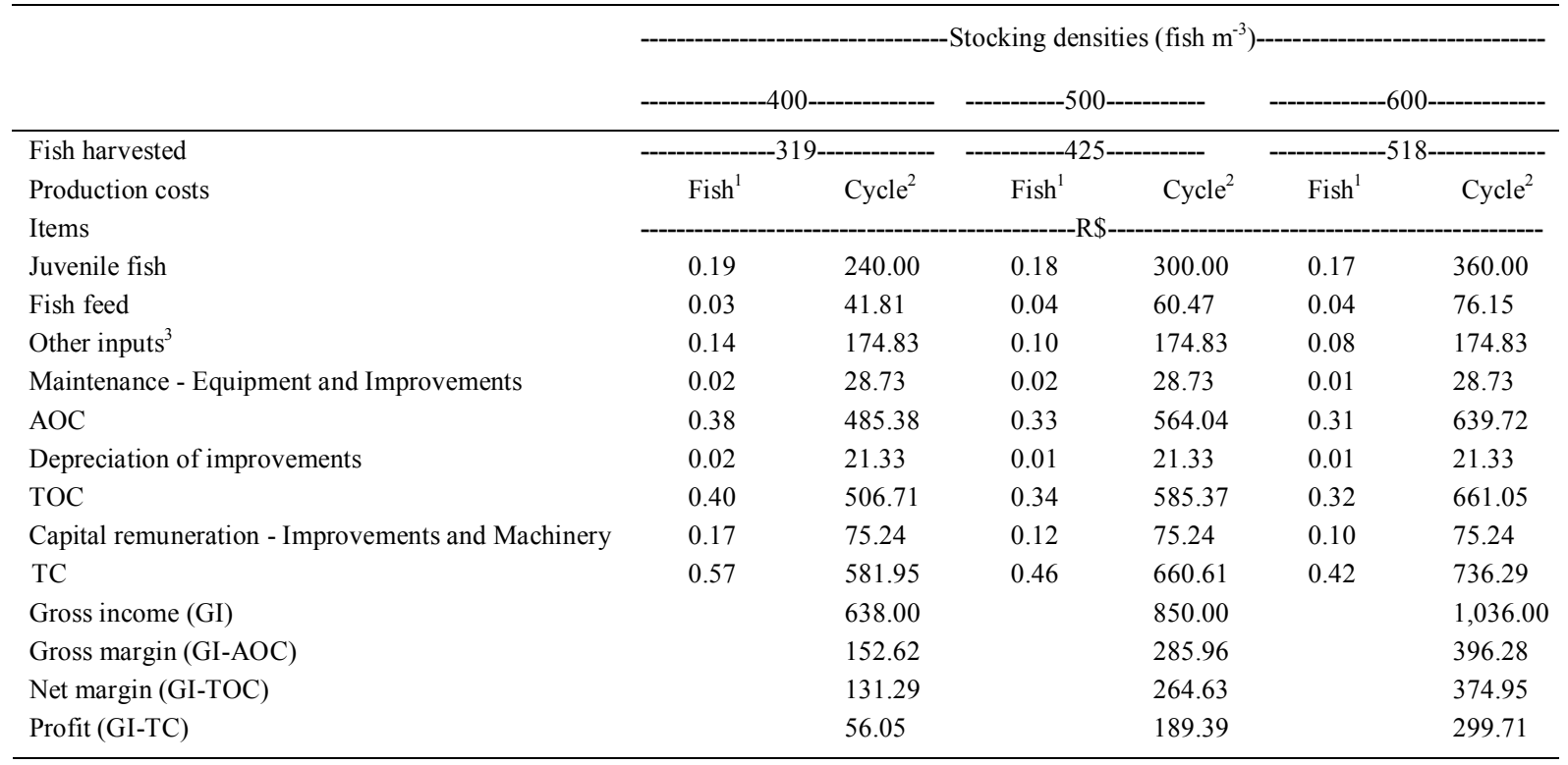

${ }^{1}$ Production cost per fish unit produced. ${ }^{2}$ Production cost per production cycle in four net-pens. ${ }^{3}$ Expenses with fuel, water analysis, and salt for fish measurements. AOC: actual operating cost; TOC: total operating cost; TC: total cost.

Ciência Rural, v.46, n.1, jan, 2016. 
tested. At 400 and 500 fish $\mathrm{m}^{-3}$, cost per unit was higher as less fish was produced than at 600 fish $\mathrm{m}^{-3}$. Nevertheless, cost per cycle was lower at 400 and $500 \mathrm{fish}^{-3}$ than at $600 \mathrm{fish}^{-3}$, as less fish produced may include lower inputs, e.g., feed and juveniles. Financial performance indicators per cycle for each of the stocking densities have shown that the production is economically feasible in the short and the long terms, and the activity is profitable even when expenses with capital remuneration are discounted (Table 2). Initial growout phase of juvenile tambatinga at a density of 600 fish $\mathrm{m}^{-3}$ results in better margins and higher profit than at 400 or 500 fish $\mathrm{m}^{-3}$ (Table 2). This result was a consequence of the high yield with high density, compensating the higher total cost.

Initial grow-out phase of tambaqui was also economically feasible with tambaqui in earthen ponds (CAVERO et al., 2009). Juvenile tambaqui of $1.5-2.0 \mathrm{~g}$ were stocked for 45 days and market price of $80-\mathrm{g}$ fish was estimated between $\mathrm{R} \$ 0.80-1.50$, with a return profit of $\mathrm{R} \$ 0.25-0.95$. Such profit is far above that found in this work and could be explained by the difference between the initial and final body weight and the productive efficiency of farming in earthen ponds, as fish have access to natural food and are subjected to lower stocking densities, resulting in a higher growth (LIMA et al., 2013).

The same relationship between stocking density and economic return has been reported for surubins Pseudoplatystoma sp. (COELHO \& CYRINO, 2006), African catfish Clarias gariepinus (HENGSAWAT et al., 1997), and panga Pangasius sutchi (RAHMAN et al., 2006). The same relationship was also observed during grow-out of tambaqui in net pens but with results showing positive net margin only in the high stocking density (GOMES et al., 2006).

\section{CONCLUSION}

Based on yield, stress physiological indicators, and profitability, the optimum stocking density for initial grow-out phase of tambatinga in net pens would be of $600 \mathrm{fish} / \mathrm{m}^{3}$.

\section{ACKNOWLEDGEMENTS}

The authors are thankful to José Silva Leão Filho and Diego Lemes Leão, small-scale fish farmers, for the provision of the experimental area and assistance during the experiment.

This study is a result of Projeto Divinópolis (Code 06.11.01.002.00.00), a project financially supported and implemented by Embrapa Pesca e Aquicultura.

\section{REFERENCES}

ANRAS, M.L.B. Demand-feeding behaviour of sea bass kept in ponds: diet and seasonal patterns, and influences of environmental factors. Aquaculture International, v.3, p.186-195, 1995. Available from: <http://link.springer.com/ article/10.1007\%2FBF00118100>. Accessed: Dec. 17, 2014. doi: 10.1007/BF00118100.

AOAC (ASSOCIATION OF OFFICIAL ANALYTICAL CHEMISTS). Official methods of analysis. 16.ed. Washington, D.C, 1999. 1141p.

ARAÚJO-LIMA, C; GOULDING, M. Os frutos do tambaqui: ecologia, conservação e cultivo na Amazônia. Tefé, AM: Sociedade Civil de Mamirauá; Brasília: CNPq, 1998. 186p.

BORBA, M. et al. Growth, lipogenesis and body composition of piracanjuba (Brycon orbignyanus) fingerlings fed different dietary protein and lipid concentrations. Aquatic Living Resources, v.16, p.362-369, 2003. Available from: <http://dx.doi.org/10.1016/ S0990-7440(03)00061-5>. Accessed: Jan. 05, 2015. doi: 10.1016/ S0990-7440(03)00061-5.

BRANDÃO, F.R. et al. Densidade de estocagem de juvenis de tambaqui durante a recria em tanques-rede. Pesquisa Agropecuária Brasileira, v.39, p.357-362, 2004. Available from: <http://dx.doi. org/10.1590/S0100-204X2004000400009>. Accessed: Nov. 19, 2014. doi: 10.1590/S0100-204X2004000400009.

BRANDÃO, F.R. et al. Densidade de estocagem de matrinxã (Brycon amazonicus) na recria em tanque-rede. Pesquisa Agropecuária Brasileira, v.40, p.299-303, 2005. Available from: $<$ http://www.scielo.br/pdf/pab/v40n3/a14v40n3.pdf $>$. Accessed: Mar. 10, 2015. doi: 10.1590/S0100-204X2005000300014.

BRAUN, N. et al. Growth, biochemical and physiological responses of Salminus brasiliensis with different stocking densities and handling. Aquaculture, v.301, p.22-30, 2010. Available from: $<$ http://www.sciencedirect.com/science/article/pii/ S0044848610000566>. Accessed: Nov. 19, 2014. doi: 10.1016/j. aquaculture.2010.01.022.

CAVERO, B.A.S. et al. Criação comercial do tambaqui Colossoma macropomum (Cuvier, 1818). In: TAVARES-DIAS, M. Manejo e sanidade de peixes em cultivo. Macapá: Embrapa Amapá, 2009. Cap.2, p.33-46.

CHAGAS, E.C.et al. Produtividade de tambaqui criado em tanquerede com diferentes taxas de alimentação. Ciência Rural, v.37, n.4, p.1109-1115, 2007. Available from: <http://dx.doi.org/10.1590/ S0103-84782007000400031>. Accessed: Oct. 22, 2014. doi: $10.1590 / \mathrm{S} 0103-84782007000400031$.

CHAGAS, E.C. et al. Desempenho de tambaqui cultivado em tanques-rede, em lago de várzea, sob diferentes taxas de alimentação. Pesquisa Agropecuária Brasileira, v.40, p.833835, 2005. Available from: <http://dx.doi.org/10.1590/S0100204X2005000800015>. Accessed: Nov. 20, 2014. doi: 10.1590/ S0100-204X2005000800015.

COELHO, S.R.C.; CYRINO, J.E.P. Custos na produção intensiva de surubins em gaiolas. Informações econômicas, v.36, p.7-14, 2006.

FAO. World aquaculture 2010. Rome: FAO, 2011. 105p. (FAO Fisheries and Aquaculture Department. Technical Paper, n. 
500/1). Available from: <http://www.fao.org/docrep/014/ba0132e/ ba0132e.pdf $>$. Online. Accessed: Dec. 09, 2014.

FURLANETO, F.P.B. et al. Custo e rentabilidade da produção de tilápia em tanque-rede no Médio Paranapanema, estado de São Paulo, safra 2004/05. Informações Econômicas, v.36, p.63-69, 2006.

GOMES, L.C. et al. Cage culture of tambaqui (Colossoma macropomum) in a central Amazon floodplain lake. Aquaculture, v.253, p.374-384, 2006. Available from: $<$ http://www.sciencedirect. com/science/article/pii/S0044848605005442>. Accessed: Oct. 01, 2014. doi: 10.1016/j.aquaculture.2005.08.020.

HASHIMOTO, D.T. et al. Interspecific fish hybrids in Brazil: management of genetic resources for sustainable use. Reviews in Aquaculture, v.4,p.108-118,2012. Available from: $<$ http://onlinelibrary. wiley.com/doi/10.1111/j.1753-5131.2012.01067.x/abstract $>$. Accessed: Oct. 24, 2014. doi: 10.1111/j.1753-5131.2012.01067.x.

HENGSAWAT, K. et al. The effect of stocking density on yield, growth and mortality of african catfish (Clarias gariepinus Burchell 1822) culture in cages. Aquaculture, v.152, 67-76, 1997. Available from: $<$ http://www-sciencedirect-com.ez103.periodicos. capes.gov.br/science/article/pii/S0044848697000082>. Accessed: Oct. 22, 2014. doi: 10.1016/S0044-8486(97)00008-2.

INOUE, L.A.K.A. et al. Evaluation of tambaqui metabolic responses to eugenol in anesthetics baths. Acta Amazonica, v.41, n.2, p.327-332, 2011. Available from: <http://dx.doi.org/10.1590/ S0044-59672011000200020>. Accessed: Oct. 20, 2014. doi: 10.1590/S0044-59672011000200020.

KAWARAZUKA, N.; BÉNÉ, C. Linking small-scale fisheries and aquaculture to household nutritional security: an overview. Food Security, v.2, p.343-357, 2010. Available from: <http://link. springer.com/article/10.1007/s12571-010-0079-y>. Accessed: Nov. 12, 2014. doi: 10.1007/s12571-010-0079-y.

KOHLA, U. et al. Growth, digestive enzyme activities and hepatic glycogen levels in juvenile Colossoma macropomum Cuvier from South America during feeding, starvation and refeeding. Aquaculture and Fisheries Management, v.23, p.189-208, 1992. Available from: <http://onlinelibrary.wiley.com/ doi/10.1111/j.1365-2109.1992.tb00610.x/abstract>. Accessed: Nov. 28, 2014. doi: 10.1111/j.1365-2109.1992.tb00610.x.

KUBITZA, F.; ONO, E. Piscicultura familiar como ferramenta para o desenvolvimento e segurança alimentar no meio rural. Panorama da Aquicultura, v.20, p.14-23, 2010.

LIMA, A.F. et al. Engorda de peixes. In: RODRIGUES, A.P.O.et al. (Ed.). Piscicultura de água doce: multiplicando conhecimentos. Brasília: Embrapa, 2013. Cap.10, p.347-377.

LIMA, A.F. et al. Metodologia para o monitoramento de dados técnicos e econômicos em pisciculturas familiares. Palmas: Embrapa Pesca e Aquicultura, 2014. 68p. (Boletim de Pesquisa e Desenvolvimento, 4).
MORO, G.V. et al. Dietary non-protein energy sources: growth, digestive enzyme activities and nutrient utilization by the catfish jundiá, Rhamdia quelen. Aquaculture Research, v.41, p.394-400, 2010. Available from: $<$ http://onlinelibrary.wiley.com/doi/10.1111/ j.1365-2109.2009.02352.x/full>. Accessed: Jan. 05, 2014. doi: 10.1111/j.1365-2109.2009.02352.x.

MORO, G.V. et al. Monitoramento e manejo da qualidade da água em pisciculturas. In: RODRIGUES, A.P.O. et al. (Ed.). Piscicultura de água doce: multiplicando conhecimentos. Brasília: Embrapa, 2013. Cap.5, p.171-213.

OLIVEIRA, E.G. et al. Effects of stocking density on the performance of juvenile pirarucu (Arapaima gigas) in cages. Aquaculture, v.370-371, p.96-101, 2012. Available from: <http:// dx.doi.org/10.1016/j.aquaculture.2012.09.027>. Accessed: Nov. 19, 2014. doi: 10.1016/j.aquaculture.2012.09.027.

PETIT, G. et al. Density effects on food intake and growth of largemouth bass (Micropterus salmoides). Aquaculture Research, v.32, p.495-497, 2001. Available from: <http:// onlinelibrary.wiley.com/doi/10.1046/j.1365-2109.2001.00589.x/ pdf $>$. Accessed: Nov. 19, 2014. doi: 10.1046/j.13652109.2001.00589.x.

RAHMAN, M.M. et al. Cage culture of sutchi catfish, Pangasius sutchi (Fowler 1937): effects of stocking density on growth, survival, yield and farm profitability. Aquaculture Research, v.37, p.33-39, 2006. Available from: <http://onlinelibrary.wiley. com/doi/10.1111/j.1365-2109.2005.01390.x/full>. Accessed: Oct. 22, 2014. doi: 10.1111/j.1365-2109.2005.01390.x.

SABBAG, O.J. et al. Custos e viabilidade econômica da produção de lambari-do-rabo-amarelo em Monte Castelo/SP: Um estudo de caso. Boletim do Instituto de Pesca, v.37, p.307-315, 2011.

SILVA, A.M.D. et al. Growth, yield, water and effluent quality in ponds with different management during tambaqui juvenile production. Pesquisa Agropecuária Brasileira, v.42, p.733740, 2007b. Available from: <http://dx.doi.org/10.1590/S0100204X2007000500017>. Accessed: Nov. 12, 2014. doi: 10.1590/ S0100-204X2007000500017.

SILVA, A.P. et al. Diagnóstico participativo da piscicultura familiar na região de Divinópolis/TO: Uma abordagem diferenciada para ações de pesquisa e desenvolvimento. Palmas: Embrapa Pesca e Aquicultura, 2013. 92p. (Boletim de Pesquisa e Desenvolvimento, 2).

SILVA, C.R. et al. Effect of feeding rate and frequency on tambaqui (Colossoma macropomum) growth, production and feeding costs during the first growth phase in cages. Aquaculture, v.264, p.135139, 2007a. Available from: <http://www.sciencedirect.com/ science/article/pii/S0044848606009069>. Accessed: Nov. 20, 2014. doi: 10.1016/j.aquaculture.2006.12.007.

WEDEMEYER, G.A. Physiology of fish in intensive culture systems. New York: Chapman \& Hall, 1996. 232p. 